\title{
Attracting girls to information technology
}

\author{
Jenny Brown
}

National Council for Educational

Coventry

United Kingdom

\begin{abstract}
There is evidence $[1,2]$ which indicates that girls in the UK continue to be less likely than boys to get involved in using IT or to pursue careers in IT. Contributory factors are difficulties in getting access to computers, the absence of positive female role models, lack of awareness by intermediaries such as teachers and careers staff, lack of parental and social encouragement, and the absence of software which will capture the early interest of girls. The needs of girls and young women embarking on their careers, and of particular groups, such as ethnic minority girls, need to be addressed. The National Council for Educational Technology (NCET) and the Women Into Information Technology Foundation Ltd. (WIT) have launched a joint project to develop and pilot change initiatives for employers, educators and parents in order to encourage girls to pursue careers in IT.
\end{abstract}

Main conference themes: equity issues

Educational areas:

Study topics: computer literacy

Secondary keywords: attitudes 


\section{INTRODUCTION}

\section{The Problem}

In the UK, Her Majesty's Inspectorate has reported that girls continue to be less likely than boys to enthuse about IT, and more likely to take on passive roles when working alongside boys. The Department for Education has reported that between 1986 and 1988, the percentage of school leavers gaining a graded result in computing was twice as high for boys as for girls. The Women into Information Technology Foundation (WIT) has highlighted that in higher education entry to computer science courses by females dropped from $24 \%$ in 1978 to just over $10 \%$ in 1991 . This although female entry to subjects such as mathematics, physics, chemistry and engineering increased in the same period. The proportion of women in the professional IT workforce has also fallen from $22 \%$ to $21 \%$ over the past year. But for the trend towards recruiting more mature women, the fall in numbers to date would have been much stronger. In addition, WIT has reported that the situation in the UK is considerably worse than in France, the US and the Far East, where women form a much higher proportion of the IT workforce.

\section{The Evidence}

The reasons why girls fail to engage with computers were identified very early in their use in education. Research carried out in the United States produced a list of twelve barriers to equitable instruction with computers including lack of encouragement to females and ethnic minority students, limited access for female students, few female role models, and a bias against females and minorities in software and advertising. Two years later it was found that although there was no lack of female interest in computing, boys were forging ahead in every computer related field except word processing, a traditionally female skill. In Canada a survey of over 3,000 grade 11 students looked at recreational and nonrecreational home use of computers and the use of computers in school. The survey showed that girls were less likely to be frequent computer users than boys and that the reasons for this difference were to do with girls' problems of access both at home and in school, their personal attitude to computers and society's stereotypical view of computer users.

In the UK Culley [1] found a number of reasons why girls in school were not enthusiastic about computers. In mixed schools there were problems for girls in gaining access to computers, with boys sometimes physically pushing them away. She noted an absence of positive female role models with whom girls could identify and a general assumption that computers were not for girls. Computer tasks were set in inappropriate contexts for girls often relating to male sporting interests and demanding competitive rather than collaborative 
learning styles. By contrast girls in single sex schools had none of these problems and were consequently more enthusiastic about computing. Girls got easy access to computers, were most often taught by female teachers and the context in which the learning was set, the style of learning and the resources used were more relevant to their interests. It is therefore not surprising that Culley found that in choosing options for examination courses or careers girls in mixed schools failed to choose computing. A recent NCET/WIT [4] study on access to IT-related careers for ethnic minority girls found little change. A major obstacle was still the lack of positive role models with whom the girls could identify. Factors such as lack of information on careers in IT, lack of parental support and encouragement, lack of awareness of stereotyping on the part of teachers and careers officers, and the timing of schools' option choices all inhibit girls' interest in using IT.

In a speech given in 1990, John McGregor, (the then Minister for Education), identified many of these factors which he saw as impeding the take up of both courses and careers in computing by girls and women and called for a more enlightened attitude.

\section{Access}

Studies [2] have shown that girls are thirteen times less likely than boys to have a computer at home, and that having access at home increases children's enthusiasm and confidence and encourages them to see computers as useful. Martin also found that when girls do have access to computers at home they are less likely to use them to play games but are more attracted to software which they see as useful, such as word processors.

\section{Attitude}

Male and female attitudes to computers were examined in a study [5] of undergraduates who used computers as part of their curriculum, but who were not computer science students. Overall there was no difference in male and female attitudes to computers, but women were significantly more negative about their own ability with computers than men, who tended to overestimate their ability. In Australia [6] it was found that girls had higher anxiety levels about using computers, boys higher computer interest. He identified possible causes to be social beliefs about computer use, teacher sex bias, and software - particularly games - more geared to boys' interests. In a longitudinal study [7, p. 20] looking at responses to computers by 339 public school students in Tennessee, it was found that boys were consistently more positive about computer use than girls and that there was no evidence of change over the course of the three year study. 


\section{Role Models}

The importance of strong female role models in encouraging girls to take up courses and careers in computing has been shown by numerous studies. Durndell et al. [8] in a study of 387 college first year students examined reasons for the low female uptake on computing courses. Findings were that lack of role models together with fear of intimidation influenced those females who avoided computer courses. By contrast it was found that girls responded well to a computing science degree course set up at Thames Polytechnic because care was taken to ensure that students worked with positive female role models and in collaborative rather than competitive learning styles. A case study from the SMILE Project, reported in Girls and Computers edited by Celia Hoyles (1988) records the confidence displayed by one girl whose mother worked with computers. This positive role model encouraged the daughter to see herself as a computer user and in fact to become the classroom 'expert'.

\section{Learning styles}

The way in which learning takes place with computers, is important if girls are to be encouraged. The learning task, the context in which it is set and the style in which it is to be completed, are all factors contributing to its perceived relevance to girls. Morse and Daiute [9] found that when research was focused on what girls liked about computers, for example activities not related to mathematics or programming, female students expressed positive, enthusiastic and confident feelings about computers. David Kirk, [10] in examining gender issues through a review of the literature of information technology in schools, found that gender differences in the learning processes and innate perceptual differences were influencing factors. Learning styles were seen as a major influence on the lack of female students in computer classrooms and occupations by Gerver and Lewis in 1984 who examined women and computers in adult education. Collaborative learning styles have been found to be important factors in successful computer courses specifically designed for female students. In 1989 Murphy described a successful action research project funded by the European Community in Northern Ireland which designed and introduced a new university qualification in information technology specifically targeted at women. This resulted in a high success rate of the women finding jobs and the promotion of positive attitudes in the women, their families and employers.

\section{Resources}

Software and teaching materials for computer courses should appeal to a cross section of students from varying backgrounds. The reality is that most software is devised to appeal to white males. Biraimah [11, p. 16] evaluated a 
sample of 15 software programs on the bases of gender and ethnicity. She found that patterns of gender and ethnic imbalance previously noted in textbooks were present in the software. Males were shown as active characters and in more science and technology roles, while females were limited to fewer and more passive roles. A recent study by Trayhurn [12] in a Leeds primary school concluded that images used in educational software designed to be viewed as neutral by their designers, were ascribed as male gender by the five and six year children interviewed. The context in which the images are presented, was seen to be important if the highly developed stereotypical view of genders which are in place on entry to primary school, are to be set aside.

\section{SOME STRATEGIES AND SOLUTIONS}

To remedy the current situation, a number of strategies is required which target teachers, parents, careers staff, employers and the girls themselves.

Awareness raising is a major issue and there is a need for information to be provided on role models of young women working with information technology and on routes into these careers, including qualifications and training. Teachers also need ideas and strategies to help them ensure that girls and boys have equal access to computers, and to encourage girls to opt for courses traditionally followed by boys. The National Curriculum has helped in terms of equal access because it is now mandatory for every pupil to develop information technology capability through the cross curricular use of computers. But inequality of access to courses still exists as much of the work offered is still more likely to appeal to boys rather than girls. However, the inclusion of the Attainment Targets for Information Technology within the Technology curriculum has led to the design of some innovative courses which offer girls more attractive options. For example, the Richard Aldworth Community School in Basingstoke has created a 'Design for Living' course which combines computer studies, design, food technology, construction, control technology and business studies. The wider scope has attracted greater numbers of girls than the traditional computer studies course.

Awareness also needs to be raised with parents. Girls need to be bought computers at home as well as their brothers and they need to be encouraged by parents and teachers to see themselves as computer users.

One reason for lack of enthusiasm on the part of girls for both science and technology is thought to be the lack of technically related preschool activities undertaken by girls. A study, in 1990, gave a group of both girls and boys, aged 5-8 years, equal structured access to construction materials found that the 
gender gap in achievement in science and technology narrowed. One encouraging observation, from a pilot project looking at Integrated Learning Systems in Schools currently being undertaken for the Department for Education by the NCET, is that because the computers must be carefully managed and each child allocated a computer at a specific time each day, girls no longer have to fight for access. The girls in the project are as enthusiastic as the boys about this new way of learning and have no reluctance or technophobia.

Attitudes in both education and industry need to be changed so that information technology is seen as important for girls and women. Managers and policy makers need to be made aware of the changes needed within their institutions in order to remove obstacles, and, once aware, require support for planning and implementing change.

The information technology industry itself also needs to be influenced to take on board the needs of girls. Software producers and developers need to be informed of the issues and encouraged to produce user-friendly software with content which appeals to girls as well as boys.

\section{THE ROLE OF THE NCET/WIT DEVELOPMENTAL PROJECT}

The National Council for Educational Technology (NCET) and The Women into Information Technology Foundation Ltd (WIT) are currently working collaboratively on a major developmental project, sponsored by government and industry, to encourage both girls and women to use IT, and to follow IT-related careers. This project further complements and enhances work already being carried out by WIT [3], the aim of which is to encourage more girls to enter and sustain careers in IT

During the first phase of the project, (September 1993-March 1994) the focus was on awareness raising activities. An information pack targeted at schools, policy makers in education and industry, was published. Production of a video raising key issues and showing role models of young women working with IT is now complete. The video emphasizes positive female role models within computing. The young women featured in the film were employed in a range of careers showing that the use of IT is now an important part of most jobs and that the ability to use it creatively is essential in many career areas. One area featured was that of software design and this was presented as a problem solving task set in a social context. The importance of demonstrating that girls could use their abilities to communicate, to solve problems and to work collaboratively in IT careers was recognized $[5,10]$. 
The second phase of the project (April 94-March 95) plans to build on existing research, by identifying and filling gaps in the available evidence, extracting key messages and strategies, and promoting these to education and industry through, for example, high profile consultative seminars. A first seminar was held in Nottingham in November 1994, sponsored by industry for an audience of industrialists, higher education tutors and headteachers $[8,10]$.

Workshops at the seminar produced outcomes which will inform the next stage of the project. A second industry sponsored seminar will be held in March 1995 for MPs, high level industrialists and other key policy makers.

A pack of workshop ideas has been produced aimed at teachers and careers advisers. The target group for these materials was 13-14 year-old girls and the aim was to raise their awareness of IT and to encourage them to take advantage of opportunities to use computers in school. At this age girls will be involved in making subject choices for external examinations and will be beginning to think about possible careers [1]. The materials were designed above all to show that computing can be fun. The activity sheets are designed to look like pages from a teenage magazine and the information is shown in a context which is relevant to girls of this age.

The final phase of the project (April 1995-March 1996) will continue to promote and disseminate project findings and materials, through activities including seminars, exhibitions, and press coverage. A final report will assess and evaluate the overall impact of the project.

\section{REFERENCES}

1. Culley, L. (1988) Girls, boys and computers. Educational Studies 14 (1) p. 38.

2. Martin, R. (1991) School children's attitudes towards computers as a function of gender, course subjects and availability of home computers. Journal of Computer Assisted Learning 7 (3) pp. 187-194.

3. Women Into Information Technology Foundation Ltd. (1993) The Nightmare Unfolds. Spring 1993 IT Skills Trends Report. WIT.

4. NCET/WIT (1993) Access to IT careers: improving opportunities for ethnic minority girls. NCET (unpublished).

5. Davies, A. (1993) Women and Technology. Assistant Librarian, October 1993. 
6. Okebukola, P. A. (1993) The gender factor in computer anxiety and interest among some Australian high school students. Educational Research 35 (2) pp. 181-89.

7. Krendl, K. A. (1991) Student responses to computers: A longitudinal study. Paper presented at the annual meeting of the International Communication Association, Chicago.

8. Durndell, A. et al (1990) Gender differences and computing in course choice at entry into higher education. British Educational Research Journal 6 (2) pp. 149-162.

9. Morse, F. K. and Daiute, C. (1992) I LIKE computers versus I LIKERT computers: Rethinking methods for assessing the gender gap in computing. Paper presented at the annual conference of the American Educational Research Association, San Francisco.

10. Kirk, D. (1992) Gender issues in Information Technology as found in schools: authentic/synthetic, fantastic? Educational Technology 32 (4) pp. 2835.

11. Biraimah, K. (1989) Inequalities in classroom computer software. Paper presented at the annual meeting of the Eastern Educational Research Association, Savannah, USA.

12. Trayhurn, D. (1994) An Investigation into gender bias in educational software in a Leeds Primary School. GAMMA Newsletter 20. 